\title{
Modulation by fatty acids of $\mathrm{Ca}^{2+}$ fluxes in sarcoplasmic-reticulum vesicles
}

\author{
Cristiana M. CARDOSO and Leopoldo DE MEIS* \\ Instituto de Ciências Biomédicas, Departamento de Bioquímica, Universidade Federal do Rio de Janeiro, Cidade Universitária, Ilha do Fundão, Rio de Janeiro 21941-590, \\ Brasil
}

The fatty acids palmitic $\left(\mathrm{C}_{16: 0}\right)$, stearic $\left(\mathrm{C}_{18: 0}\right)$, arachidic $\left(\mathrm{C}_{20: 0}\right)$ and arachidonic $\left(\mathrm{C}_{20: 4}\right)$ acids inhibit $\mathrm{Ca}^{2+}$ uptake and enhance $\mathrm{Ca}^{2+}$ efflux measured in vesicles derived from the sarcoplasmic reticulum of skeletal muscle. These effects of the fatty acids are impaired by the $\mathrm{Ca}^{2+}$-ATPase ligands $\mathrm{Mg}^{2+}, \mathrm{Ca}^{2+}$ and $\mathrm{K}^{+}$, and by drugs that block the leakage of $\mathrm{Ca}^{2+}$ through the $\mathrm{Ca}^{2+}$-ATPase such as Ruthenium Red, spermine [de Meis (1991) J. Biol. Chem. 266, 5736-5742] and thapsigargin [de Meis and Inesi (1992) FEBS Lett. 299, 33-35].

\section{INTRODUCTION}

Vesicles derived from the light fraction of the sarcoplasmic reticulum of rabbit skeletal muscle retain a membrane-bound $\mathrm{Ca}^{2+}$-ATPase (EC 3.6.1.38) [1]. This protein is able to pump $\mathrm{Ca}^{2+}$ into the vesicles at the expense of ATP hydrolysis. The pump can be reversed and $\mathrm{Ca}^{2+}$ can be released from the vesicles in a process coupled with the synthesis of ATP from ADP and $P_{1}$ [1-4]. The reversal of the $\mathrm{Ca}^{2+}$ pump is initiated by phosphorylation of the enzyme by $P_{i}$, which forms an acylphosphate residue at the catalytic site of the enzyme [4,5]. This reaction is highly dependent on the $\mathrm{Mg}^{2+}$ concentration in the medium and is inhibited by $\mathrm{Ca}^{2+}\left(K_{\mathrm{s}}=10^{-6} \mathrm{M}\right), \mathrm{K}^{+}\left(K_{\mathrm{a}}=10^{-4} \mathrm{M}\right)$, Ruthenium Red, the polyamines spermidine and spermine [5-9], and thapsigargin, a highly specific inhibitor of $\mathrm{Ca}^{2+}$-ATPase [10-12].

The ATPase is asymmetrically embedded in the membrane with two domains, an extramembranous catalytic site facing the cytoplasm and a transmembrane helical domain responsible for $\mathrm{Ca}^{2+}$ translocation $[13,14]$. Coupling between catalysis and $\mathrm{Ca}^{2+}$ transport is not well understood at present. Measurements of $\mathrm{Ca}^{2+}$ efflux from $\mathrm{Ca}^{2+}$-loaded vesicles showed that, in the absence of other enzyme ligands, the portion of the ATPase molecule where the catalytic site is located is no longer able to control the part of the protein involved in $\mathrm{Ca}^{2+}$ translocation. As a result, $\mathrm{Ca}^{2+}$ leaks through the ATPase at a rate similar to that observed during the reversal of the pump [15]. This leakage is greatly increased by hydrophobic drugs such as phenothiazines, $\beta$ adrenergic blocking agents and anaesthetics $[9,12,16]$. The $\mathrm{Ca}^{2+}$ leakage through the pump measured with and without hydrophobic drugs is abolished by the ATPase ligands $\mathrm{P}_{1}, \mathbf{M g}^{2+}, \mathrm{K}^{+}$ and $\mathrm{Ca}^{2+}$ and by the same drugs that impair the reversal of the $\mathrm{Ca}^{2+}$ pump, i.e. thapsigargin, Ruthenium Red and polyamines. Experimental evidence indicates that the effect of these drugs on the rate of $\mathrm{Ca}^{2+}$ efflux is related to their binding to the enzyme and not to alterations of the physical state of the membrane lipids $[9,12]$.

Fatty acids, particularly arachidonic acid, are known to regulate several physiological events in different cell types [17-23]. Fatty acids are also known to produce a variety of effects on sarcoplasmic-reticulum vesicles; these depend on concentration, acyl chain length, degree of saturation, and experimental conditions used [24-30]. The effects observed seem to be promoted by interaction of the fatty acids added with the membrane phospho- lipids surrounding the ATPase [29,31]. In this report we show that, similarly to the phenothiazines, the saturated fatty acids $\left(\mathrm{C}_{16}, \mathrm{C}_{18}\right.$ and $\left.\mathrm{C}_{20}\right)$ and arachidonic acid $\left(\mathrm{C}_{20: 4}\right)$ inhibit $\mathrm{Ca}^{2+}$ accumulation and stimulate $\mathrm{Ca}^{2+}$ efflux from the vesicles. The effects of these fatty acids are antagonized by the same substances that impair the effects of the phenothiazines, suggesting a common mechanism of action.

\section{MATERIALS AND METHODS}

Sarcoplasmic-reticulum vesicles were prepared from rabbit skeletal muscle as described by Eletr and Inesi [32]. In this preparation the rate of $\mathrm{Ca}^{2+}$ efflux is not altered by ryanodine concentrations ranging from 0.4 to $10 \mu \mathrm{M}$ [9], and gel electrophoresis reveals only minimal traces of the ryanodine-sensitive $\mathrm{Ca}^{2+}$-channel protein [33].

ATP hydrolysis was determined by measuring the release of $\left[{ }^{32} \mathrm{P}\right] \mathrm{P}_{\mathrm{i}}$ from [ $\left.{ }^{32} \mathrm{P}\right] \mathrm{ATP}$ [34].

$\mathrm{Ca}^{2+}$ uptake and efflux were measured by a filtration method using Millipore filters [35] and ${ }^{45} \mathrm{Ca}$. After filtration, the filters were washed with $3 \times 5 \mathrm{ml}$ of $3 \mathrm{mM} \mathrm{La}\left(\mathrm{NO}_{3}\right)_{3}$, and the radioactivity remaining on the filters was counted in a liquidscintillation counter.

For the efflux experiment, the vesicles were preloaded in a medium with $50 \mathrm{mM}$ Mops/Tris, pH 7.0, $10 \mathrm{mM} \mathrm{MgCl}_{2}, 20 \mathrm{mM}$ $P_{i} ; 0.3 \mathrm{mM}{ }^{45} \mathrm{CaCl}_{2}, 2 \mathrm{mM}$ ATP and $0.06 \mathrm{mg} / \mathrm{ml}$ sarcoplasmicreticulum vesicles. After $30 \mathrm{~min}$ at $35^{\circ} \mathrm{C}$, most of the $\mathrm{Ca}^{2+}$ present in the medium was taken up by the vesicles. The loaded vesicles were sedimented by centrifugation at $30000 \mathrm{~g}$ for $20 \mathrm{~min}$, the supernatant was discarded, and the walls of the tubes were blotted to minimize contamination by the residual loading medium. The pellet was kept on ice and resuspended in water immediately before use. The efflux medium contained $40 \mathrm{mM}$ Mops/Tris, pH 7.0, $2 \mathrm{mM}$ EGTA, $0.1 \mathrm{mM} P_{i}$ and $0.1 \mathrm{mM}$ $\mathrm{MgCl}_{2}$. For the efflux measurements, the vesicle concentration was $0.01 \mathrm{mg}$ of protein $/ \mathrm{ml}$. Other additions were as indicated in the legends of the Figures. All experiments were performed at $\mathrm{pH} 7.0$ and at $35^{\circ} \mathrm{C}$.

Fatty acids were dissolved in ethanol. The amounts used were such that the ethanol concentration in the reaction mixture was never higher than $0.5 \%(\mathrm{v} / \mathrm{v})$. At this concentration, ethanol had no effect on either $\mathrm{Ca}^{2+}$ uptake or $\mathrm{Ca}^{2+}$ efflux. Unsaturated fatty acids were kept under $\mathrm{N}_{2}$ to avoid spontaneous oxidation. All the

\footnotetext{
* To whom correspondence should be addressed.
} 
Table 1 Effects of $\mathrm{Mg}^{2+}, \mathrm{K}^{+}, \mathrm{Na}^{+}$and $\mathrm{LI}^{+}$on the Inhibltion of $\mathrm{Ca}^{2+}$ uptake Induced by fatty aclds

The reaction-medium composition was $50 \mathrm{mM}$ Mops/Tris buffer (pH 7.0), $2 \mathrm{mM}$ ATP, $20 \mathrm{mM}$ $P_{1}, 0.1 \mathrm{mM} \mathrm{CaCl}{ }_{2}$ and the additions shown below. Control experiments were performed with $1 \mathrm{mM} \mathrm{MgCl}$. The reaction time was $20 \mathrm{~min}$. Values are means \pm S.E.M. of 3-7 experiments.

\begin{tabular}{lllll}
\hline \multicolumn{5}{c}{ Inhibition of $\mathrm{Ca}^{2+}$ uptake (\%) } \\
\cline { 2 - 5 } Additions & $\begin{array}{l}\mathrm{C}_{16: 0} \\
(50 \mu \mathrm{M})\end{array}$ & \multicolumn{1}{l}{$\begin{array}{l}\mathrm{C}_{18: 0} \\
(16 \mu \mathrm{M})\end{array}$} & $\begin{array}{l}\mathrm{C}_{20: 0} \\
(16 \mu \mathrm{M})\end{array}$ & $\begin{array}{l}\mathrm{C}_{20: 4} \\
(8 \mu \mathrm{M})\end{array}$ \\
\hline Control & $63.3 \pm 3.8$ & $73.3 \pm 6.7$ & $66.9 \pm 2.8$ & $95.0 \pm 1.0$ \\
$10 \mathrm{mM} \mathrm{MgCl}$ & $22.5 \pm 1.5$ & $11.2 \pm 4.1$ & $10.2 \pm 3.1$ & $54.2 \pm 5.1$ \\
$100 \mathrm{mM} \mathrm{KCl}$ & $18.3 \pm 2.4$ & $13.6 \pm 1.8$ & $13.6 \pm 2.2$ & $87.2 \pm 1.2$ \\
$100 \mathrm{mM} \mathrm{NaCl}$ & - & - & $9.8 \pm 3.7$ & $74.3 \pm 7.6$ \\
$100 \mathrm{mM} \mathrm{LiCl}$ & - & - & $8.9 \pm 2.0$ & $85.0 \pm 9.2$ \\
\end{tabular}

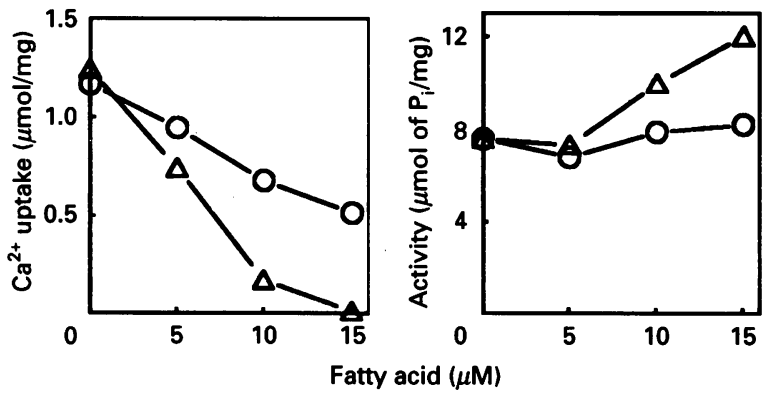

Figure 1 Effects of arachidic and arachidonic acids on $\mathrm{Ca}^{2+}$ uptake (a) and ATPase activity (b)

The reaction-medium composition was $40 \mathrm{mM}$ Mops/Tris buffer (pH 7.0), $2 \mathrm{mM}$ ATP, $20 \mathrm{mM}$ $P_{i}, 0.1 \mathrm{mM} \mathrm{CaCl}$ and $1 \mathrm{mM} \mathrm{MgCl}_{2}$. Reaction was started by the addition of vesicles to a final concentration of $0.01 \mathrm{mg} / \mathrm{ml}$. The reaction time was $10 \mathrm{~min}$. $O$. Arachidic acid $\left(C_{20: 0}\right) ; \Delta$, arachidonic acid $\left(\mathrm{C}_{20: 4}\right)$.

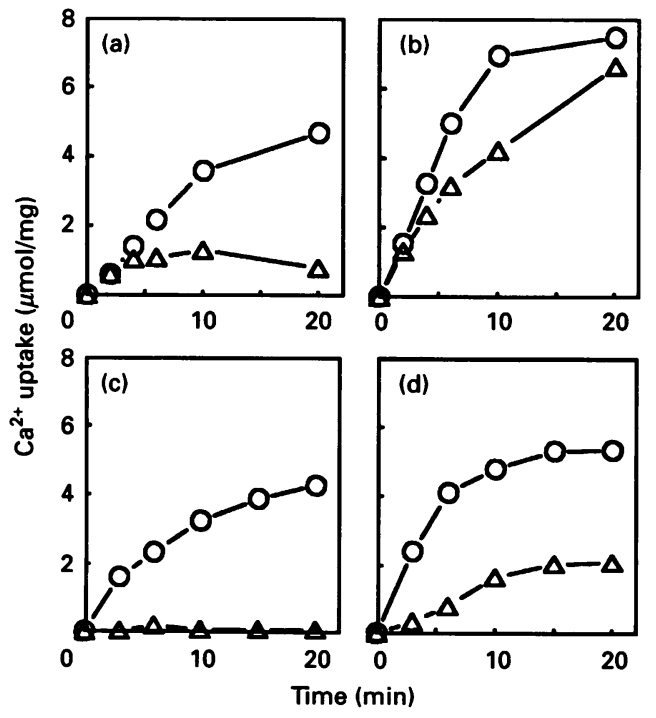

Figure 2 Effect of $\mathbf{M g}^{2+}$

The reaction medium composition was $50 \mathrm{mM}$ Mops/Tris buffer (pH 7.0), $2 \mathrm{mM} \mathrm{ATP,} 20 \mathrm{mM}$ $\mathrm{P}_{\mathrm{i}}, 0.1 \mathrm{mM} \mathrm{CaCl}{ }_{2}$ and $0.01 \mathrm{mg} / \mathrm{ml}$ vesicles. The $\mathrm{MgCl}_{2}$ concentrations used were $1 \mathrm{mM}$ in (a) and (c) and $10 \mathrm{mM}$ in (b) and (d). O. Control; $\triangle, 16 \mu \mathrm{M}$ stearic acid $\left(\mathrm{C}_{16: 0}\right)$ (a and $\mathbf{b}$ ) or $16 \mu \mathrm{M}$ arachidonic acid $\left(\mathrm{C}_{20: 4}\right)$ (c and $\mathrm{d}$ ).
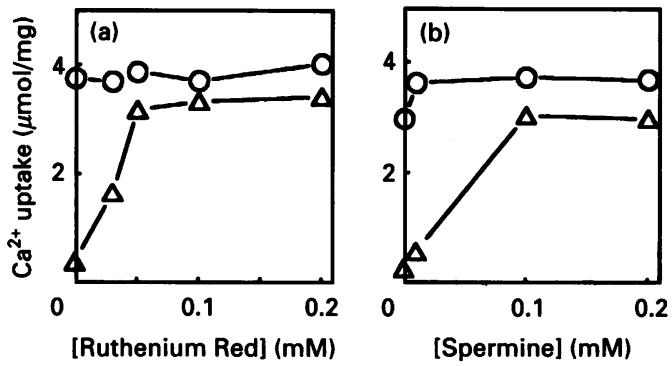

Figure 3 Effect of Ruthenium Red and spermine on the inhibition of $\mathrm{Ca}^{2+}$ uptake Induced by arachidonic acid

The reaction medium was the same as in Figure 1 . The reaction time was $20 \mathrm{~min}$. $\mathrm{O}$, No addition; $\triangle, 16 \mu \mathrm{M}$ arachidonic acid $\left(\mathrm{C}_{20: 4}\right)$.

fatty acid solutions were freshly prepared. Fatty acids were obtained from Sigma.

The data shown in this paper are representative of experiments that were repeated with at least three preparations.

\section{RESULTS}

\section{Effects of saturated and unsaturated fatty acids on $\mathrm{Ca}^{2+}$ uptake and ATPase activity}

$\mathrm{Ca}^{2+}$ uptake was inhibited by the different fatty acids tested (Table 1). In agreement with Katz et al. [29], we found that unsaturated fatty acids were more effective inhibitors than were the saturated acids. This was measured by using arachidonic acid $\left(\mathrm{C}_{20: 4}\right)$ and arachidic acid $\left(\mathrm{C}_{20: 0}\right)$ (Figure 1a). The ATPase activity was not impaired by these acids (Figure 1b); on the contrary, it was activated by arachidonic acid $\left(\mathrm{C}_{20: 4}\right)$. Thus the inhibition of $\mathrm{Ca}^{2+}$ uptake seems to be related to a decrease in the rate of pumping, but rather to leakage of $\mathrm{Ca}^{2+}$ accumulated by the vesicles [1].

The inhibition of $\mathrm{Ca}^{2+}$ uptake promoted by the different fatty acids decreased when the $\mathrm{MgCl}_{2}$ concentration in the medium was raised from 1.0 to $10.0 \mathrm{mM}$ (Table 1 and Figure 2). $\mathrm{Mg}^{2+}$ was more effective in antagonizing the effect of saturated than of unsaturated fatty acids (Table 1).

The univalent cations $\mathrm{K}^{+}, \mathrm{Na}^{+}$and $\mathrm{Li}^{+}$were also able to decrease the inhibition promoted by the saturated fatty acid $\left(\mathrm{C}_{\text {20:0}}\right)$ but, as observed for $\mathrm{Mg}^{2+}$, had only a minimal effect when arachidonic acid $\left(\mathrm{C}_{20: 4}\right)$ was used (Table 1$)$.

The organic compounds Ruthenium Red and spermine antagonized the effects of unsaturated fatty acids (Figure 3). In control experiments without fatty acids, these organic compounds had no effect on the rate of $\mathrm{Ca}^{2+}$ uptake.

\section{Effect of fatty acids on $\mathrm{Ca}^{2+}$ effilux}

Both saturated and unsaturated fatty acids were found to increase the rate of $\mathrm{Ca}^{2+}$ efflux (Figure 4). This was observed when vesicles preloaded with calcium phosphate were diluted in a medium containing EGTA and low concentrations of $P_{i}$ and $\mathrm{Mg}^{2+} . \mathrm{Ca}^{2+}$ inhibited the efflux induced by saturated fatty acids, but had little or no effect on the efflux induced by arachidonic acid (Figure 5a and Table 2). The $\mathrm{Ca}^{2+}$ concentration in the medium needed to antagonize the effect of saturated fatty acids was in the same range as that needed to saturate the high-affinity $\mathrm{Ca}^{2+}$ binding site of the ATPase [36]. The effects of both saturated and unsaturated fatty acids on the rate of $\mathrm{Ca}^{2+}$ efflux were 


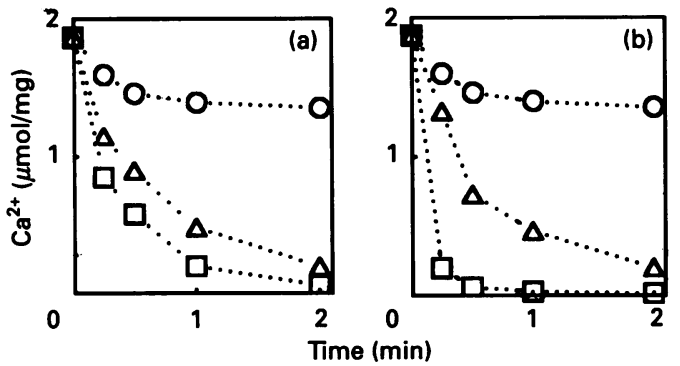

Figure 4 Effect of fatty acids on the rate of $\mathrm{Ca}^{2+}$ effilux

The reaction-medium composition was $50 \mathrm{mM}$ Mops/Tris buffer $(\mathrm{pH} 7.0), 0.1 \mathrm{mM} \mathrm{P}_{\mathrm{p}}, 0.1 \mathrm{mM}$ $\mathrm{MgCl}_{2}, 2 \mathrm{mM}$ EGTA and $0.01 \mathrm{mg} / \mathrm{ml}$ vesicles previously loaded with ${ }^{45} \mathrm{Ca}$. (a) $\mathrm{O}$, no addition; $\triangle, 16 \mu \mathrm{M}$ stearic acid $\left(C_{18: 0}\right) ; \square, 32 \mu \mathrm{M}$ stearic acid $\left(C_{18: 0}\right) ;(b) O$, no addition; $\triangle$, $8 \mu \mathrm{M}$ arachidonic acid $\left(\mathrm{C}_{20: 4}\right) ; \square, 16 \mu \mathrm{M}$ arachidonic acid $\left(\mathrm{C}_{20: 4}\right)$. The symbols show the ${ }^{45} \mathrm{Ca}$ remaining in the vesicles after incubation in the efflux medium for the times shown on the abscissae.
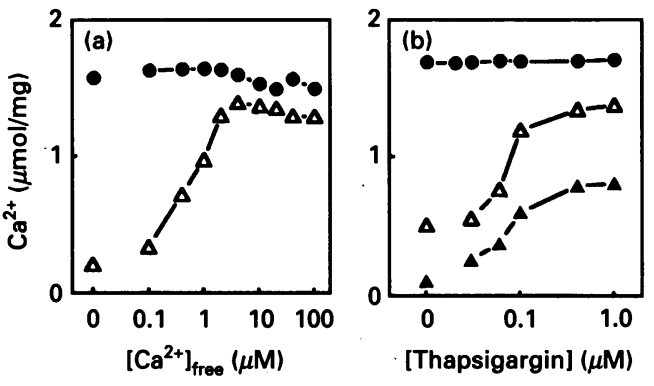

Figure 5 Effects of $\mathrm{Ca}^{2+}$ (a) and thapsigargin (b) on the increased rate of $\mathrm{Ca}^{2+}$ effilux induced by fatty acid

In (a) the reaction medium and experimental conditions were as described in Figure 4. The efflux time was $1 \mathrm{~min}$. No addition; $\triangle, 16 \mu \mathrm{M}$ stearic acid $\left(\mathrm{C}_{18: 0}\right)$. The free $\mathrm{Ca}^{2+}$ concentration was calculated by using the apparent association constants for $\mathrm{Ca} / \mathrm{EGTA}$ provided by Schwartzenbaeh and Flaschka [37] using a computer program as described by Fabiato and Fabiato [38]. In (b), the efflux medium composition was: $0,4 \mathrm{mM} \mathrm{P}, 10 \mathrm{mM} \mathrm{MgCl}$ and no fatty acid; $\triangle . \Delta, 50 \mathrm{mM}$ Mops/Tris buffer ( $\mathrm{pH} 7.0), 0.1 \mathrm{mM} \mathrm{P}, 0.1 \mathrm{mM} \mathrm{MgCl}, 2 \mathrm{mM}$ EGTA and either $(\triangle) 8 \mu \mathrm{M}$ or $(\boldsymbol{\Delta}) 16 \mu \mathrm{M}$ arachidonic acid $\left(\mathrm{C}_{20: 4}\right)$. The concentration of loaded vesicles was $0.01 \mathrm{mg} / \mathrm{ml}$ and the efflux time was $2 \mathrm{~min}$.

\section{Table $2 \mathrm{Ca}^{2+}$ effilux}

The reaction was started by addition of vesicles $(0.010 \mathrm{mg}$ of protein $/ \mathrm{ml})$ loaded with $2.0-2.3 \mu \mathrm{mol}$ of $\mathrm{Ca}^{2+} / \mathrm{mg}$ of protein. The reaction mixture contained $50 \mathrm{mM}$ Mops $/$ Tris buffer (pH 7.0), $2 \mathrm{mM}$ EGTA, $0.1 \mathrm{mM} \mathrm{P}, 0.1 \mathrm{mM} \mathrm{MgCl}$ and the additions shown below. The $\mathrm{Ca}^{2+}$. efflux rates are the difference between the ${ }^{45} \mathrm{Ca}$ in the vesicles before and after $1 \mathrm{~min}$ incubation at $35^{\circ} \mathrm{C}$. Values are means \pm S.E.M. of $3-7$ experiments.

\begin{tabular}{|c|c|c|c|}
\hline \multirow[b]{2}{*}{ Additions } & \multicolumn{3}{|c|}{$\begin{array}{l}\text { Rate of } \mathrm{Ca}^{2+} \text { efflux } \\
\text { ( } \mu \mathrm{mol} / \mathrm{min} \text { per } \mathrm{mg} \text { of protein) }\end{array}$} \\
\hline & Control & $\begin{array}{l}\mathrm{C}_{20: 0} \\
(16 \mu \mathrm{M})\end{array}$ & $\begin{array}{l}\mathrm{C}_{20: 4} \\
(16 \mu \mathrm{M})\end{array}$ \\
\hline None & $0.23 \pm 0.04$ & - & - \\
\hline Fatty acid & - & $1.42 \pm 0.08$ & $2.23 \pm 0.02$ \\
\hline $\mathrm{MgCl}_{2}(10 \mathrm{mM})$ & $0.01 \pm 0.01$ & $0.18 \pm 0.03$ & $0.01 \pm 0.08$ \\
\hline $\mathrm{KCl}(100 \mathrm{mM})$ & $0.04 \pm 0.02$ & $0.06 \pm 0.09$ & $0.61 \pm 0.14$ \\
\hline $\mathrm{CaCl}_{2}(0.1 \mathrm{mM})$ & $0.01 \pm 0.02$ & $0.16 \pm 0.08$ & $1.96 \pm 0.05$ \\
\hline Ruthenium Red (0.1 mM) & $0.01 \pm 0.01$ & $0.01 \pm 0.01$ & $0.16 \pm 0.02$ \\
\hline Spermine (1 mM) & $0.02 \pm 0.01$ & $0.09 \pm 0.03$ & $1.31 \pm 0.06$ \\
\hline Thapsigargin $(1 \mu \mathrm{M})$ & $0.02 \pm 0.01$ & $0.85 \pm 0.03$ & $1.02 \pm 0.03$ \\
\hline
\end{tabular}

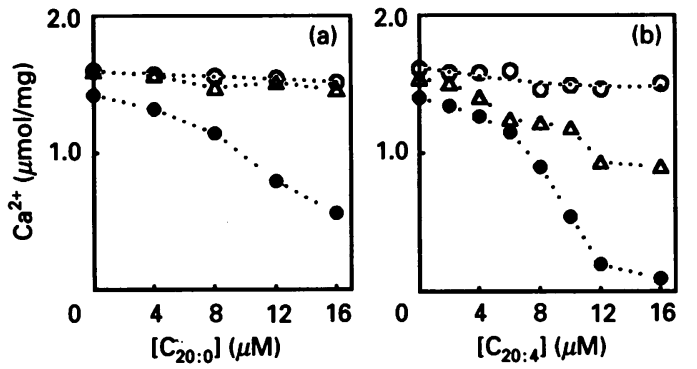

Figure 6 Effect of Ruthenium Red and spermine on the increased rate of $\mathrm{Ca}^{2+}$ effilux induced by saturated (a) and unsaturated (b) fatty acids

The reaction medium and experimental conditions were as described in Figure 4. Time of efflux was $1 \mathrm{~min}$. No addition; $0,100 \mu \mathrm{M}$ Ruthenium Red; $\triangle, 2 \mathrm{mM}$ spermine.

impaired by addition of $\mathrm{Mg}^{2+}, \mathrm{K}^{+}$, Ruthenium Red, spermine or thapsigargin (Figures $5 \mathrm{~b}$ and 6 , and Table 2). The effect of arachidonic acid on the $\mathrm{Ca}^{2+}$ efflux (Table 2) was antagonized more effectively by $\mathrm{K}^{+}$than in $\mathrm{Ca}^{2+}$-uptake measurements (Table 1). The ability of thapsigargin to antagonize the effect of arachidonic acid varied, depending on the concentration of the fatty acid used (Figure $5 \mathrm{~b}$ ). In the conditions of Table 2, a halfmaximal effect was obtained with $1 \mu \mathrm{M}$ thapsigargin.

\section{DISCUSSION}

Among the different fatty acids tested, arachidonic acid was found to be the most active, not only as an inhibitor of $\mathrm{Ca}^{2+}$ uptake but also as an agent for increasing the rate of $\mathrm{Ca}^{2+}$ efflux. At present we do not know why the response observed with $\mathrm{Ca}^{2+}$ and $\mathrm{K}^{+}$varies depending on whether a saturated or an unsaturated fatty acid is used (Figure 5a, Tables 1 and 2). Two hypotheses could be raised: (1) saturated and unsaturated fatty acids have different sites of action; (2) they are acting on the same site, but the affinity of the saturated fatty acid for the site is lower than the affinity of the unsaturated fatty acid, and therefore the former is more easily displaced. In a previous study [9] it was shown that phenothiazines uncouple the $\mathrm{Ca}^{2+}$ pump of the sarcoplasmic reticulum and greatly increase the leakage of $\mathrm{Ca}^{2+}$ through the ATPase. The finding that the effects of both phenothiazines and fatty acids are antagonized by the transport ATPase ligands $\mathrm{Ca}^{2+}, \mathrm{Mg}^{2+}$ and $\mathrm{K}^{+}$, as well as by Ruthenium Red, spermine and thapsigargin, suggests that phenothiazines and fatty acids uncouple the pump by the same mechanism. The mechanism by which $\mathrm{Ca}^{2+}, \mathrm{Mg}^{2+}, \mathrm{K}^{+}$, Ruthenium Red and spermine increase coupling of the pump has been discussed in detail in previous reports dealing with effects of phenothiazines $[9,12,16]$. Thapsigargin is a specific inhibitor of the $\mathrm{Ca}^{2+}$-ATPase. It stabilizes the ATPase in the $\mathrm{E}_{2}$ conformation, blocking both the phosphorylation of the $E_{2}$ form by $P_{1}$ and the $E_{2}-E_{1}$ interconversion of the enzyme. Thus the $\mathrm{Ca}^{2+}$ pump is locked and $\mathrm{Ca}^{2+}$ ions can no longer be translocated in either direction, to or from the vesicles [10-12]. The increment in efflux promoted by $8 \mu \mathrm{M}$ arachidonic acid is completely antagonized by thapsigargin. However, the increment in efflux promoted by higher arachidonic acid concentrations is only partially impaired by thapsigargin. This raises the possibility that fatty acids may interact with two different regions of the membrane. At low concentrations they would bind only to the enzyme, and the resulting increment in $\mathrm{Ca}^{2+}$ efflux would be arrested by thapsigargin. At higher concentrations the fatty acids would bind to the ATPase and, in addition, alter the interactions of the ATPase with the membrane 
phospholipids [29]. In this case $\mathrm{Ca}^{2+}$ would leave the vesicles through a second route which would not be affected by thapsigargin.

This work was supported by grants from Conselho Nacional de Desenvolvimento Científico e Technológico (CNPq), and by Financiadora de Estudos e Projetos (FINEP). C.M.C. is recipient of a fellowship from Coordenação de Aperfeiçoamento de Pessoal de Nível Superior (CAPES).

\section{REFERENCES}

1 de Meis, L. (1981) in The Sarcoplasmic Reticulum: Transport and Energy Transduction (Bittar, E., ed.), vol. 2, John Wiley and Sons, New York

2 Tantord, C. (1984) CRC Crit. Rev. Biochem. 17, 123-151

3 de Meis, L. (1989) Biochim. Biophys. Acta 973, 333-349

4 de Meis, L. and Vianna, A. (1979) Annu. Rev. Biochem. 48, 275-292

5 Masuda, H. and de Meis, L. (1973) Biochemistry 12, 4581-4585

6 Beil, F. U., Chak, D. and Hasselbach, W. (1977) Eur. J. Biochem. 81, 151-164

7 Chaloub, R. M. and de Meis, L. (1979) J. Biol. Chem. 255, 6168-6172

8 Alves, E. W. and de Meis, L. (1986) J. Biol. Chem. 261, 16854-16859

9 de Meis, L. (1991) J. Biol. Chem. 266, 5736-5742

10 Witcome, M., Henderson, I., Lee, A. G. and East, J. M. (1992) Biochem. J. 283, $525-529$

11 Sagara, Y., Fernandez-Beida, F., de Meis, L. and Inesi, G. (1992) J. Biol. Chem. 267, 12606-12613

12 de Meis, L. and Inesi, G. (1992) FEBS Lett. 299, 33-35

13 MacLennan, D. H., Brandl, C. J., Korczac, B. and Green, N. M. (1985) Nature (London) 316, 696-700

14 Clarke, D. M., Loo, T. W. and MacLennan, D. H. (1990) J. Biol. Chem. 265, 6262-6267

15 de Meis, L., Suzano, V. A. and Inesi, G. (1990) J. Biol. Chem. 265, 18848-18851
16 Wolosker, H., Pacheco, A. G. F. and de Meis, L. (1992) J. Biol. Chem. 267, 5785-5789

17 Randriamampita, C. and Trautmann, A. (1990) J. Biol. Chem. 265, 18059-18062

18 Hoffman, T., Lizzio, E. F., Ting, A., Marshall, L. A., Bonvini, E. and Jennings, M. K. (1987) Clin. Immunol. Immunopathol. 44, 82-92

19 Ordway, R. W., Walsh, J. V. and Singer, J. J. (1989) Science 244, 1176-1178

20 Giaume, C., Randriamampita, C. and Trautmann, A. (1989) Pflugers Arch. 413, 273-279

21 Piomelli, D., Volterra, A., Dale, N., Siegelbaum, S. A., Kandel, E. R., Schwartz, J. H. and Belardetti, F. (1987) Nature (London) 328, 38-43

22 Halenda, S. P., Banga, H. S., Zavoico, G. B., Lau, L. F. and Feinstein, M. B. (1989) Biochemistry 28, 7356-7363

23 Zietler, P. and Handwerger, S. (1985) Mol. Pharmacol. 28, 549-554

24 Hasselbach, W. and Makinose, M. (1962) Biochem. Biophys. Res. Commun. 7, 132-136

25 Sarzala, M. G. and Drabikowski, W. (1969) Life Sci. 8, 477-483

26 Messineo, F., Pinto, P. and Katz, A. M. (1980) J. Mol. Cell. Cardiol. 12, 725-732

27 Warren, G. B., Toon, P. A., Birdsall, N. J. M., Lee, A. G. and Metcalfe, J. C. (1974) Biochemistry 13, 5501-5507

28 Cheah, A. (1981) Biochim. Biophys. Acta 648, 113-119

29 Katz, A. M., Nash-Adler, P., Watras, J., Messineo, F., Takenaka, H. and Louis, C. F. (1982) Biochim. Biophys. Acta 687, 17-26

30 Herbette, L., Messineo, F. C. and Katz, A. M. (1982) Annu. Rev. Pharmacol. Toxicol. 22, 413-434

31 Michelangeli, F., Grimes, E. A., East, J. M. and Lee, A. G. (1991) Biochemistry 30 , 342-351

32 Eletr, S. and Inesi, G. (1972) Biochim. Biophys. Acta 282, 174-179

33 Inesi, G. and de Meis, L. (1989) J. Biol. Chem. 264, 5929-5936

34 Grubmeyer, C. and Penefsky, H. S. (1981) J. Biol. Chem. 256, 3718-3727

35 Chiesi, M. and Inesi, G. (1979) J. Biol. Chem. 254, 10370-10377

36 Inesi, G., Kurzmack, M., Coan, C. and Lewis, D. E. (1980) J. Biol. Chem. 255, 3025-3031

37 Schwartzenbach, G. and Flaschka, H. (1965) Die komplexometrische titration, Euke Verlag, Stuttgart

38 Fabiato, A. and Fabiato, F. (1979) J. Physiol. (Paris) 75, 463-505

Received 26 April 1993/6 July 1993; accepted 12 July 1993 